\title{
Developments in HIV-I immunotherapy and therapeutic vaccination
}

\author{
Peter Lawrence Smith*, Helen Tanner and Angus Dalgleish
}

Address: St George's, University of London, Institute for Infection and Immunity, 1 Cranmer Terrace, London SW17 0RE, UK

* Corresponding author: Peter Lawrence Smith (plsmith@sgul.ac.uk)

Fl000Prime Reports 2014, 6:43 (doi:10.12703/P6-43)

All FI000Prime Reports articles are distributed under the terms of the Creative Commons Attribution-Non Commercial License (http://creativecommons.org/licenses/by-nc/3.0/legalcode), which permits non-commercial use, distribution, and reproduction in any medium, provided the original work is properly cited.

The electronic version of this article is the complete one and can be found at: http://f1000.com/prime/reports/m/6/43

\begin{abstract}
Since the human immunodeficiency virus (HIV-I) pandemic began, few prophylactic vaccines have reached phase III trials. Only one has shown partial efficacy in preventing HIV-I infection. The introduction of antiretroviral therapy (ART) has had considerable success in controlling infection and reducing transmission but in so doing has changed the nature of HIV-I infection for those with access to ART. Access, compliance, and toxicity alongside the emergence of serious non-AIDS morbidity and the sometimes poor immune reconstitution in ART-treated patients have emphasized the need for additional therapies. Such therapy is intended to contribute to control of HIV-I infection, permit structured treatment interruptions, or even establish a functional cure of permanently suppressed and controlled infection. Both immunotherapy and therapeutic vaccination have the potential to reach these goals. In this review, the latest developments in immunotherapy and therapeutic vaccination are discussed.
\end{abstract}

\section{Introduction}

An effective prophylactic vaccine for HIV-1 remains elusive [1]. Few vaccines have entered phase III trials and only one has shown partial protection against HIV-1 infection [2]. Although insight gained from these trials is informing future vaccine research, the current failures have prompted the development of strategies aimed at eradicating the virus in infected individuals. Such efforts to induce a "sterilizing cure" include gene therapy and stem cell therapy. The recent report of an HIV-1-infected patient who after transplantation with chemokine receptor 5 (CCR5) $\Delta 32 / \Delta 32$ stem cells was absent of detectable viral replication despite the cessation of ART provides encouragement that, in principle, eradication is an achievable goal [3]. However, it remains to be seen whether any eradication approaches are effective or practical on a large scale, and thus ART remains the best means of controlling both infection of individuals and the HIV-1 epidemic.

ART has been very successful in reducing the rate of HIV-1 infection and progression to AIDS. Treatment of
ART early in infection has been shown to reduce the transmission of HIV-1 from person to person [4], whilst examples of early, intensive ART administration have demonstrated an ability to clear detectable infection in a new-born child [5]. The use of ART as a pre-exposure prophylactic treatment in high-risk groups has resulted in a reduction in HIV-1 infection, providing evidence that ART can be used to effectively reduce the incidence of HIV-1 infection in addition to controlling existing infection [6].

\section{Problems with antiretroviral therapy}

Despite the success of ART, there are problems associated with its use and this emphasizes the need for additional therapies, particularly those permitting breaks in ART medication. ART is ineffective against latent viral reservoirs [7] and does not completely stop expression of some HIV-1 genes. This failure necessitates continued ART for life, which is logistically difficult and expensive, particularly in low- to middle-income countries in which the majority of HIV-1-infected individuals reside. The generation of ART-resistant strains of HIV-1 continues to 
be a problem [8], and the need for continued ART creates issues in both access and compliance along with complications associated with ART use. Such complications include metabolic syndrome [9], increased cardiovascular disease [10], quality-of-life changes [11], and organ damage [12]. Not surprisingly, side effects associated with ART are linked with non-compliance [13]. Whilst ART has reduced the incidence of HIV-1-associated neurodegenerative disorders (HANDs), many HIV-1 patients with successful ART therapy still exhibit HANDs. Penetration of ART across the blood-brain barrier is problematic and may not reach central nervous system compartments of HIV-1 infection [14]. Conversely, some antiretroviral drugs are associated with neurological side effects $[15,16]$. Finally, initiation of ART in patients with HIV-1 and a co-infection such as tuberculosis risks the onset of immune reconstitution inflammatory syndrome $[17,18]$. Thus, although ART is vital in treating HIV-1 infection, reliance on ART creates additional problems to be addressed.

The success of antiretroviral therapy as a lifelong treatment has transformed the nature of HIV-1 infection. In successfully treated individuals, HIV-1 infection is now a chronic immunological disease [19]. Delaying the initiation of ART or planned interruption is associated with increases in morbidity and mortality, and yet continued treatment of ART over a number of decades causes toxicity. Evidence suggests that even antiretroviralnaïve patients with normal $\mathrm{CD} 4{ }^{+} \mathrm{T}$-cell counts are at a greater risk of suffering from serious HIV-1 associated non-AIDS diseases [20], highlighting the potential use of ART in patients with good CD4+ T cell counts and yet patients successfully treated with ART often fail to adequately reconstitute healthy immune responses [21].

The mechanism of this immune dysfunction is thought to be the immune activation induced by HIV-1. This immune activation involves innate inflammatory responses such as monocyte activation and production of pro-inflammatory cytokines, including interleukin (IL)-6. Skewed T-cell ratios, generalized T-cell activation, ineffective T-cell effector functions, and the selective depletion of T-cell subsets, particularly $\mathrm{T}$ helper 17 (Th17) cells and effector memory $\mathrm{CD}^{+} \mathrm{T}$ cells, are also observed in HIV-1-dependent immune activation.

\section{HIV-I-dependent immune activation}

The causes of immune activation and dysfunction are not completely understood. Lipopolysaccharide translocation across damaged mucosal barriers contributes to immune activation by creating an inflammatory environment within the mucosa-associated lymphoid tissue [22].
Depletion of CD4+ T-cells, particuarly Th17 cells, in the gut leading to compromised mucosal barrier function is thought to be important in this process, but it is unclear how the Th17 cells are being depleted when only a fraction of $\mathrm{T}$ cells are actually infected [23-25]. Other factors influencing immune activation include sensitivity to type I interferon and co-infection. It is likely that multiple factors relating to viral replication synergize to promote the activation and subsequent dysregulation of the immune system, but it is currently unclear which factors are principal causes rather than consequences of HIV-1-induced immune activation. It is also unknown why some level of immune failure continues to persist after HIV-1 replication has been effectively controlled by ART. Prophylactic or therapeutic vaccination will likely need to address immune activation in order to succeed. A large number of immunotherapy approaches have been studied for their ability to improve anti-HIV-1 immune responses and control infection. These include both non-specific immunotherapy and antigen-specific therapeutic vaccination. Both approaches will be described here with a focus on some of the most notable recent studies in immunotherapy and therapeutic vaccination.

\section{Immunotherapy}

Immunotherapy, aimed at reducing inflammation, preventing immune activation by HIV-1, or promoting effective immune responses, is currently being investigated (Table 1). Diverse approaches are being studied, and a number of trials are completed or under way.

\section{Antibody therapy}

Antibodies used to either enhance immune responses or inhibit negative regulatory pathways are being investigated. Increases in programmed cell death (PD)-1 are associated with immune dysfunction in HIV-1-positive patients [26], and in vitro antibody blockade of PDligand (L)-1 and IL10R $\alpha$ results in increases in cytokine expression, including interferon-gamma (IFN- $\gamma$ ) in HIV1 -infected patients [27]. Memory $\mathrm{CD} 4^{+} \mathrm{T}$ cells expressing high levels of PD-1 contain more proviral DNA than PD-1-low cells, and blocking PD-1 may activate HIV-1 replication and thus facilitate the clearance of these infected cells.

Anti-cytotoxic T-lymphocyte antigen 4 (CTLA4) has been studied for its ability to enhance immune responses to tumors [28]. T regulatory cells express high levels of CTLA4 and are implicated in inhibiting immune responses during HIV-1 infection. In vitro experiments using cells from healthy and HIV-1-infected individuals showed that CTLA4 is upregulated in the $\mathrm{CD} 4^{+} \mathrm{T}$ cells 
Table I. Selected recent immunotherapy for HIV-I infection

\begin{tabular}{|c|c|c|c|}
\hline Immunotherapy & Treatment & Responses & Reference \\
\hline \multicolumn{4}{|c|}{ Promoting immune responses } \\
\hline \multirow[t]{3}{*}{ Cytokines } & IL-2 during ART treatment interruptions & No evidence of improved HIV-I-specific immunity & [35] \\
\hline & $\begin{array}{l}\text { IL-7 dose escalation trial in } \\
\text { ART-treated patients }\end{array}$ & Increases in $\mathrm{CD}^{+}{ }^{+} \mathrm{T}$-cell numbers & {$[37]$} \\
\hline & $\begin{array}{l}\text { IL-2I administered to SIV-infected } \\
\text { Rhesus macaques }\end{array}$ & $\begin{array}{l}\text { Increases in natural killer-cell and } \mathrm{CD}^{+} \mathrm{T} \text {-cell function and ThI } 7 \text { cells } \\
\text { and a reduction in bacterial translocation and immune activation }\end{array}$ & {$[38,39]$} \\
\hline Drugs & Immunomodulatory drugs & $\begin{array}{l}\text { Enhanced T-cell responses to dendritic cells electroporated with } \\
\text { GAG or NEF mRNA }\end{array}$ & {$[46]$} \\
\hline \multicolumn{4}{|c|}{ Correcting immune activation and dysfunction } \\
\hline \multirow[t]{2}{*}{ Drugs } & Aspirin & Reductions in CD38, HLA-DR, and sCDI4 & [40] \\
\hline & COX-2 inhibitor celecoxib & Celecoxib reduced the expression CD38 and inflammatory markers & [4I] \\
\hline \multirow[t]{3}{*}{ Antibodies } & Anti-PD-I & $\begin{array}{l}\text { Blocking PD-I results in increased cytokine expression in HIV-I } \\
\text { patients }\end{array}$ & {$[27]$} \\
\hline & $\begin{array}{l}\text { Anti-CLTA4 treatment of } \\
\text { SIV-infected macaques }\end{array}$ & Decreased TGF- $\beta$, IDO, and viral RNA in SIV-infected macaques & {$[30]$} \\
\hline & Anti-CCR5 Maraviroc & $\begin{array}{l}\text { Reduction in CD38 HLA-DR-expressing } \mathrm{CD}^{+} \mathrm{T} \text { cells and normalized } \\
\mathrm{CD}^{+} \mathrm{T} \text {-cell skewing }\end{array}$ & {$[32]$} \\
\hline \multirow[t]{2}{*}{ Probiotics } & Symbiotic plus dietary fiber & No alteration in bacterial translocation & [48] \\
\hline & Prebiotic and probiotic & Reductions in bacterial DNA, CD4 ${ }^{+}$T-cell counts, and IL-6 & [49] \\
\hline
\end{tabular}

ART, antiretroviral therapy; COX-2, cyclooxygenase type 2; IDO, indoleamine 2,3-dioxygenase; IL, interleukin; SIV, simian immunodeficiency virus; TGF- $\beta$, transforming growth factor-beta.

from infected patients and inversely correlated with CD4 counts and anti-HIV-1 T-cell responses whilst positively correlating with the percentage of activated $\mathrm{CD}^{+} \mathrm{T}$ cells [29]. Using the anti-CTLA4 antibody MDX-010 in simian immunodeficiency virus (SIV)-infected macaques treated with ART, decreases in transforming growth factor-beta (TGF- $\beta$ ), indoleamine 2,3-dioxygenase (IDO), and viral RNA expression were observed alongside increased SIV-specific T-cell effector function [30].

The CCR5 antagonist Maraviroc is used for HIV-1 entry blockade in combination with ART [31] but also acts as an immune modulator. In a recent study on the impact of Maraviroc intensification, Maraviroc normalized HIV-1-associated $\mathrm{CD}^{+}{ }^{+} \mathrm{T}$-cell skewing and reduced the number of CD38- and human leukocyte antigen (HLA)DR-expressing $\mathrm{CD}^{+}{ }^{+} \mathrm{T}$ cells [32].

\section{Cytokines}

Reductions in IL-2 are associated with HIV-1-induced immune dysfunction. For this reason, trials were conducted in ART-treated subjects, resulting in improved $\mathrm{CD} 4^{+}$T-cell counts [33]. A trial involving intermittent IL-2 therapy of ART-naïve patients was also undertaken and demonstrated sustaining increases in $\mathrm{CD} 4^{+} \mathrm{T}$-cell numbers that could allow for deference of ART [34]. However, the recent SILCAAT (Subcutaneous Recombinant, Human Interleukin-2 in HIV-Infected Patients with Low $\mathrm{CD}^{+}$Counts under Active Antiretrovial Therapy) and ESPRIT (Evaluation of Subcutaneous Proleukin in a Randomized International Trial) trials intended to assess the effect of IL-2 in HIV-1-infected individuals with
ART-induced viral suppression revealed no evidence for improved HIV-1 immunity [35], whereas a later trial intended to assess the effect of IL-2 in ART-naïve patients demonstrated an increase in the number of $\mathrm{CD}^{+}{ }^{+} \mathrm{T}$ cells without effecting viral load [36]. These modest effects, along with toxicity associated with IL-2 therapy, have prompted research on immune modulatory properties of other cytokines during HIV-1 infection.

Alternative cytokines for improving T-cell homeostasis include IL-7 and IL-21. A dose escalation trial of recombinant human IL-7 (rhIL-7) in ART-treated HIVinfected persons was performed. Doses of rhIL-7 up to $20 \mu \mathrm{g} / \mathrm{kg}$ were tolerated and showed increases in naïve and central memory $\mathrm{CD}^{+} \mathrm{T}$ cells. In individuals with low T-cell receptor (TCR) diversity, IL-7 therapy could improve the available TCR repertoire [37].

IL-21 has recently been used in a trial of chronically untreated SIV-infected macaques in which both natural killer (NK)-cell and T-cell cytotoxicity was improved along with increased antibody production and no increases in viral load [38]. In another trial of IL-21treated SIV-infected macaques, higher levels of intestinal Th17 cells were observed and were associated with reduced levels of intestinal T-cell proliferation, microbial translocation, and systemic activation/ inflammation in the chronic infection [39]. These trials indicate that IL-21 may affect beneficial immune responses while ameliorating intestinal immune activation, making treatment with IL-21 a promising novel approach. 


\section{Anti-inflammatory and immunomodulatory drugs}

Aspirin has broad anti-inflammatory properties. HIV-1infected individuals with ART-controlled infection were administered low-dose aspirin for 1 week. After therapy, decreases in CD38 and HLA-DR expression on T cells, soluble CD14, and platelet activation were observed [40].

Cyclo-oxygenase type 2 (COX-2) inhibits T-cell activation and is upregulated in HIV-1 disease. This has prompted the investigation of COX-2 inhibitors in HIV-1 infection to determine whether they are capable of correcting immune activation. The COX-2 inhibitor celecoxib was studied in a trial of HIV-1 patients without ART. Celecoxib reduced CD38 expression of $\mathrm{CD}^{+}$ $\mathrm{T}$ cells, inflammatory markers, and the expression of PD-1 and improved vaccine responses [41].

The immunomodulatory drugs (iMiDs) thalidomide, lenalidomide, and pomalidomide have demonstrated the ability to improve immune responses [42-45]. An in vitro study of iMiDs alongside GAG or NEF mRNAelectroporated dendritic cells (DCs) resulted in higher numbers of cytokine-secreting HIV-specific $\mathrm{CD} 8^{+} \mathrm{T}$ cells, including polyfunctional HIV-specific $\mathrm{CD} 8^{+} \mathrm{T}$ cells with an enhanced lytic capacity and an ability to promote the activation of $\mathrm{CD}^{+} \mathrm{T}$ cells at a lower concentration of antigen [46]. Immunomodulatory drugs such as iMiDs warrant further studies alongside immunotherapeutic vaccination.

\section{Probiotics}

ART does not correct HIV-1-induced damage to the intestinal mucosa and only partially controls T-cell exhaustion and activation [47]. Probiotic therapy is being investigated to ameliorate this damage. In a trial in HIV-infected subjects on antiretroviral therapy, a synbiotic formulation, containing probiotic bacteria and dietary fiber, was provided each day, versus a fiber-only placebo formulation. Bacterial translocation was not altered between the probiotic bacteria and placebo groups, and markers of immune activation were unchanged [48]. Another symbiotic, a combination of pre- and probiotics, was used in a study of ART-naïve HIV-1-infected subjects [49]. Subjects received the symbiotic, just the pre- or probiotic, or placebo. Reductions in bacterial DNA, increases in $\mathrm{CD}^{+}$T-cell counts, and significant reductions in IL- 6 were observed in the symbiotic group whilst the probiotic group exhibited significant increases in beneficial bacteria and reductions in harmful bacteria such as Clostridium.

A number of diverse immunotherapy approaches are being investigated in order to promote effective immune responses. Some of these have demonstrated promising results in terms of reducing markers of immune activation or positively effecting $\mathrm{CD} 4^{+} \mathrm{T}$-cell homeostasis. However, generalized immune modulation does not specifically target HIV-1 or directly enhance anti-HIV-1specific immune responses. Given that HIV-1 patients will already exhibit some measure of immune dysfunction, even when successfully treated with ART, therapeutic vaccine approaches will be vital in the generation of therapy capable of either providing a functional cure or allowing structured treatment interruptions.

\section{Therapeutic vaccines}

T-cell immunity has emerged as a vital component of protective immune responses in HIV-1 disease [50]. Genetic polymorphisms associated with protection reside only in genes encoding HLA class I molecules [51], and effective polyfunctional T-cell immune responses to conserved HIV-1 epitopes are present in long-term nonprogressor patients who control HIV-1 infection and elite controllers [52-53]. In light of this, a number of vaccines aimed at inducing effective therapeutic immune responses are in development and most of them are intended to promote anti-HIV-1 T-cell immunity (Table 2). It is hoped that the therapeutic generation of HIV-1-specific immunity can control infection and limit transmission. Some vaccines assessed for an immunotherapeutic effect were initially designed to induce prophylactic immunity, whereas others are intended to specifically activate therapeutic T-cell immune responses.

\section{Viral vector vaccines}

Viral vectors, particularly adenovirus and pox virus, have generated considerable interest because of the low cost and ease of manufacture, along with their ability to induce gene expression within the cytosol and the large quantity of vaccine DNA that can be incorporated to induce humerol and cellular immunity after a single vaccination [54]. Although viral vector vaccines have been intended for prophylactic immunity, they also induce T-cell immune responses that may have therapeutic effects.

A phase III trial of 16,402 healthy volunteers with low risk of HIV-1 infection in Thailand measured the efficacy of a prime-boost regimen using four doses of a recombinant canarypoxvirus (ALVAC) expressing HIV gag, pro, and env genes (vCP1521) along with gp120 and Alum in the last two doses. Volunteers in the vaccine group acquired $31.2 \%$ fewer HIV-1 infections than those in the placebo group after 3 years of follow-up. Neither broadly neutralizing anti-serum nor broadly reactive T-cell responses were induced. Anti-gp120 antibodies were present in $90 \%$ of vaccinated patients after 20 weeks. Antibody-dependent cellular cytotoxicity 
Table 2. Selected recent anti-HIV-I therapeutic vaccine studies in HIV-I-positive and healthy individuals

\begin{tabular}{|c|c|c|c|c|}
\hline Vaccine type & Vaccine & Immune responses & Viral load & Reference \\
\hline \multicolumn{5}{|l|}{ Viral vector } \\
\hline ALVAC & $\begin{array}{l}\text { Recombinant canary pox viral } \\
\text { vector genetically engineered to } \\
\text { express HIV-I Gag and Pro } \\
\text { (subtype B LAI strain) and CRFOI_AE } \\
\text { (subtype E) HIV-I gp I 20, } \\
\text { administered to uninfected } \\
\text { individuals }\end{array}$ & $\begin{array}{l}\text { Weak evidence of increased CD4 } \\
\text { T-cell count upon HIV-I infection }\end{array}$ & $\begin{array}{l}\text { No overall statistically significant } \\
\text { reduction in pre-HAART viral load } \\
\text { upon HIV-I infection }\end{array}$ & {$[2,55]$} \\
\hline MVA-B & $\begin{array}{l}\text { A recombinant MVA-B-expressing } \\
\text { monomeric gp I } 20 \text { and the fused } \\
\text { Gag-Pol-Nef (GPN) polyprotein } \\
\text { of clade B }\end{array}$ & $\begin{array}{l}\text { Polyfunctional } \mathrm{CD}^{+} \text {and } \mathrm{CD} 4^{+} \\
\text {T-cell responses along with } \\
\text { Env-specific antibody responses } \\
\text { in } 95 \% \text { of volunteers }\end{array}$ & Uninfected volunteers & {$[58]$} \\
\hline NYVAC & $\begin{array}{l}\text { Phase I trial of NYVAC, expressing } \\
\text { Gag, Pol, Nef, and Env from an HIV } \\
\text { clade B isolate injected intra- } \\
\text { muscularly into I0 HIV-infected } \\
\text { patients successfully treated with } \\
\text { antiretroviral therapy }\end{array}$ & $\begin{array}{l}\text { Increased HIV-specific T-cell } \\
\text { responses in virtually all vaccines, } \\
\text { mostly GAG-specific pre-existing and } \\
\text { new detected responses }\end{array}$ & Not studied & {$[59]$} \\
\hline Ad35-GRIN & $\begin{array}{l}\text { Andovirus vector containing GAG, } \\
\text { reverse transcriptase, intergrase, } \\
\text { Nef, and Env }\end{array}$ & $\begin{array}{l}\text { Polyfunctional HIV-specific cellular } \\
\text { immune responses and humoral } \\
\text { responses }\end{array}$ & Uninfected volunteers & {$[6 I]$} \\
\hline AVXIOI & Alphavirus replicon containing GAG & Limited immune responses & Uninfected volunteers & {$[62]$} \\
\hline \multicolumn{5}{|l|}{ DNA } \\
\hline PENNVAX DNA & $\begin{array}{l}\text { Three plasmids expressing ENV, } \\
\text { GAG and Pol, plasmid containing } \\
\text { IL-I } 2\end{array}$ & $\begin{array}{l}\text { Developed } \mathrm{CD} 4^{+} \text {or } \mathrm{CD}^{+} \mathrm{T} \text {-cell } \\
\text { responses after repeat vaccination }\end{array}$ & Uninfected volunteers & {$[63]$} \\
\hline DermaVir & $\begin{array}{l}\text { Dose escalation study of plasmid } \\
\text { DNA containing I } 3 \text { complete and } \\
2 \text { non-functional HIV-I genes/ } \\
\text { proteins that self-assemble }\end{array}$ & $\begin{array}{l}\text { Induction of significantly increased } \\
\text { GAG-specific T-cell responses }\end{array}$ & Not studied & {$[66]$} \\
\hline GTU-multi-HIVB & $\begin{array}{l}\text { Phase II trial of fusion gene expressing } \\
\text { Rev, Nef, TAT, GAG + CTL epitopes } \\
\text { clusters from Pol and Env. Intrader- } \\
\text { mal and Intramuscular vaccination of } \\
\text { in HIV-I-infected ART-naïve patients }\end{array}$ & $\begin{array}{l}\text { The increase in HIV-I-specific CD4 } \\
\text { T-cells was observed predominantly } \\
\text { in the TNF- } \alpha \text {-secreting CD } 4 \text { T-cell } \\
\text { population while both HIV-I-specific } \\
\text { TNF- } \alpha \text { and IFN- } \gamma \text { CD8 } \\
\text { T-cell populations increased } \\
\text { following immunization. }\end{array}$ & $\begin{array}{l}\text { IM group with a decrease in log } \mathrm{PHIV} \text { - } \\
\text { RNA } 0.47 \text { log units }(95 \% \mathrm{Cl} \text { from } \\
-0.75 \text { to }-0.19) \text { compared with } \\
\text { placebo }(P=0.001)\end{array}$ & {$[68,69]$} \\
\hline \multicolumn{5}{|l|}{ Dendritic cell } \\
\hline $\begin{array}{l}\text { DCV2/MANON07- } \\
\text { ORVACS }\end{array}$ & $\begin{array}{l}\text { Autologous DC pulsed with whole } \\
\text { inactivated HIV-I }\end{array}$ & $\begin{array}{l}\text { Increased HIV-I-specific T-cell } \\
\text { responses }\end{array}$ & $\begin{array}{l}\text { Decrease of plasma viral load } \\
\text { setpoint } \geq I \text { log was observed in } \\
\text { vaccinated groups and was } \\
\text { associated with a consistent increase } \\
\text { in HIV-I-specific T-cell responses }\end{array}$ & [7I] \\
\hline $\begin{array}{l}\text { mRNA- } \\
\text { electroporated DC }\end{array}$ & $\begin{array}{l}\text { mRNA vaccine encoding Tat, Rev, } \\
\text { and Nef }\end{array}$ & $\begin{array}{l}\text { Induced and/or enhanced HIV-I- } \\
\text { specific CD4 }{ }^{+} \text {and } \mathrm{CD}^{+} \mathrm{T} \text {-cell but } \\
\text { did not correlate with the number } \\
\text { of weeks off cART }\end{array}$ & $\begin{array}{l}\text { Viral load in plasma unchanged from } \\
\text { historical control data }\end{array}$ & {$[72,73]$} \\
\hline \multicolumn{5}{|l|}{ Sub unit } \\
\hline Vacc4X & $\begin{array}{l}\text { Four modified peptides from the } \\
\text { GAG protein containing } M H C \\
\text { class I and II restricted epitopes }\end{array}$ & $\begin{array}{l}\text { Delayed-type hypersensitivity (DTH) } \\
\text { reactions. T-cell responses in } 80 \% \text { to } \\
90 \% \text { of patients allowing for } \\
\text { structured treatment interruption }\end{array}$ & $\begin{array}{l}\text { Significantly improved viral load ratios } \\
\text { for DTH }{ }^{\text {hi }}\left(\text { compared with DTH }{ }^{\text {lo }}\right) \\
\text { groups: } 0.58(0.27-1.33) \text { and I.26 } \\
(0.90-2.02) . \text { Correlate with stable } \\
\text { CD4 }{ }^{+} \text {T-cell counts }\end{array}$ & [74-78] \\
\hline $\begin{array}{l}\text { Subdominant } \\
\text { HIV-I peptides and } \\
\text { CAFOI }\end{array}$ & $\begin{array}{l}\text { Multiple subdominant epitopes } \\
\text { restricted to HLA supertypes }\end{array}$ & $\begin{array}{l}\text { Induction of } \mathrm{CD}^{+} \text {and } \mathrm{CD}^{+} \mathrm{T} \text {-cell } \\
\text { responses }\end{array}$ & No significant changes in viral load & [79] \\
\hline TAT & Whole TAT protein & $\begin{array}{l}\text { Modified pattern of } \mathrm{CD}^{+} \text {and } \mathrm{CD}^{+} \\
\mathrm{T} \text {-cell activation and decreased } \\
\text { markers of immune activation }\end{array}$ & Subjects on ART during study & {$[80]$} \\
\hline
\end{tabular}

ALVAC, canarypoxvirus; ART, antiretroviral therapy; cART, combination antiretroviral therapy; Cl, confidence interval; DC, dendritic cell; HAART, Highly Active Antiretroviral Therapy; IFN- $\gamma$, interferon-gamma; IL, interleukin; IM, intramuscular; MHC, major histocompatibility complex; MVA-B, modified vaccinia virus Ankara vector expressing Env, Gag, Pol, and Nef proteins of HIV-I subtype B; NYVAC, New York Vaccinia virus; TNF- $\alpha$, tumor necrosis factor-alpha. 
with gp120-coated targets was detected in $75 \%$ of vaccines for clade B gp120 but reduced by 20 weeks. $\mathrm{CD} 4^{+}$T-cell proliferation was the most substantial response detected in vaccinated individuals [2].

An extended evaluation of ALVAC in trial volunteers who subsequently acquired HIV-1 was carried out to determine whether the vaccine had therapeutic efficacy. CD4 ${ }^{+}$ T-cell counts and viral load were measured; however, the vaccine did not affect the clinical course of HIV disease after infection [55].

New York Vaccinia virus (NYVAC) and Modified vaccinia virus Ankara (MVA) are replication-deficient poxvirus vectors. They are stable and safe and can deliver a large amount of integrated DNA into cytosolic locations within an infected cell. Both vectors have been used in the development of HIV-1 vaccines. Over 30 clinical trials using MVA-based HIV-1 vaccines have been conducted [54]. Some of these trials have demonstrated impressive immunogenicity, such as the phase I trial of an MVA vector expressing Env, Gag, Pol, and Nef proteins of HIV1 subtype B (MVA-B). Three doses of MVA-B in healthy volunteers induced broad and polyfunctional $\mathrm{CD} 8^{+}$and $\mathrm{CD} 4^{+} \mathrm{T}$-cell responses along with Env-specific antibody responses in $95 \%$ of volunteers $[56,57]$.

NYVAC is highly attenuated due to the deletion of 18 open reading frames in the viral genome. NYVAC gene expression results in antigen-specific immune responses but is unable to produce infectious virus in humans. Clinical trials have been conducted by using NYVACbased HIV-1 vaccines [54]. Prime-boost vaccine protocols using DNA and NYVAC containing Env, Gag, Pol, and Nef antigens have proven to be particularly immunogenic, inducing T-cell responses in $90 \%$ of individuals, including durable and polyfunctional responses along with anti-gp140 antibody responses $[58,59]$.

Although poxvirus-based vaccines are intended primarily for prophylactic vaccination, their ability to induce broad and polyfunctional $\mathrm{CD} 8$ and $\mathrm{CD} 4^{+}$T-cell responses indicates that they also have promise as therapeutic vaccines, particularly after deletion of viral immunomodulatory genes and if vaccination strategies include immunomodulatory agents.

A phase I trial of recombinant replication-defective adenovirus serotype 35 (Ad35) vectors containing gag, reverse transcriptase, and integrase and nef (Ad35-GRIN) or env (Ad35-ENV), both derived from HIV-1 subtype A isolates, was performed. Broad and polyfunctional HIVspecific cellular immune responses and humoral responses were seen in the majority of volunteers immunized with either vaccine and increased after subsequent second vaccination [60].

AVX101, an alphavirus replicon vaccine containing HIV-1 subtype C gag, was studied in a clinical trial in healthy HIV-1-uninfected adults. AVX101 was well tolerated, however; in contrast to the preclinical data, immune responses in humans were limited. Only low levels of binding antibodies and T-cell responses were seen at the highest doses [61].

In summary, viral vectors have demonstrated the ability to induce functional immune responses and are undergoing further modification to enhance their immunogenicity. Further trials are planned.

\section{DNA vaccines}

DNA vaccination is safe and has demonstrated promising immunogenicity in animal models. These results have prompted the development of DNA-based HIV-1 vaccines. PENNVAX DNA vaccine is a mixture of three expression plasmids encoding HIV-1 Clade B Env, Gag, and Pol in addition to an IL-12 DNA plasmid. These were administered in three intramuscular vaccinations followed by electroporation. Most subjects vaccinated with PENNVAX plus IL-12 plasmid with electroporation developed either $\mathrm{CD}^{+}{ }^{+}$or $\mathrm{CD}^{+}{ }^{+} \mathrm{T}$-cell responses after repeat vaccination [62].

DermaVir is a single plasmid DNA immunogen including 13 complete and two non-functional HIV-1 proteins which self-assemble into virus-like particles [63]. In chronically infected macaques, DermaVir administered with antiretroviral drugs suppressed viral load rebound after treatment interruption and improved survival [64]. In a dose escalation study, DermaVir was found to be safe and immunogenic in HIV-1-infected individuals. HIV-specific effector $\mathrm{CD} 4^{+}$and $\mathrm{CD} 8^{+} \mathrm{T}$ cells expressing IFN- $\gamma$ and IL- 2 were detected against several antigens in every subject. DermaVir administration was associated with a trend toward greater HIV-specific, predominantly central memory T-cell responses [65], and the use of IL-7 and IL-15 as adjuvants with DermaVir significantly enhanced the number of GAG-specific central memory $\mathrm{T}$ cells from mice [66].

The DNA vaccine GTU-Multi-HIVB consists of a fusion gene expressing HIV-1 proteins Rev, Nef, and Tat as well as Gag p17/p24 and a stretch of 11 cytotoxic T lymphocyte (CTL) epitope clusters from Pol and Env [67]. The induction of $\mathrm{CD}^{+}$T-cell and antibody responses to Rev, Nef, Tat, Env, and Gag were observed in BALB/c mice. In a phase II trial of untreated, otherwise-healthy, HIV-1-infected adults, significant 
declines in log proviral RNA and increases in $\mathrm{CD} 4^{+} \mathrm{T}$-cell counts were observed in the vaccine group compared with placebo which were maintained in patients with some HLA haplotypes [68]. Early DNA-based vaccines suffered from poor immunogenicity, particularly compared with viral vectors; however, improvement in plasmid vectors, adjuvant, and delivery means that DNA vaccinations such as those detailed above warrant further study [69].

\section{Dendritic cell vaccines}

DC vaccines are attractive due to the ability to ensure that vaccine antigen reaches the cells most able to activate protective immune responses; however, they are relatively time-consuming and expensive.

In the DCV2/MANON07-ORVACS Study, autologous monocyte-derived dendritic cells (MDDCs) pulsed with heat-inactivated whole HIV have been used in a phase I trial which demonstrated immunogenicity associated with a control of viral replication. Patients on ART with $\mathrm{CD}^{+}$more than 450 cells $/ \mathrm{mm}^{3}$ received three immunizations with MDDCs or with non-pulsed MDDCs. Vaccination that resulted in significant decreases in viral load during ART interruption was associated with an increase in HIV-1-specific T-cell responses [70].

In a phase I/IIa clinical trial, HIV-1-infected ART-treated patients received four vaccinations with autologous DCs electroporated with an mRNA vaccine encoding Tat, Rev, and Nef and linked to the HLA class II-targeting sequence of DC-LAMP. ART was interrupted and after 96 weeks 6 out of 17 patients remained off therapy. Enhanced CD $4^{+}$ and $\mathrm{CD}^{+} \mathrm{T}$-cell responses specific for the immunogens were observed in most of the patients, but there was no correlation with the number of weeks off ART, and $\mathrm{CD} 4^{+}$ T-cell counts and plasma viral load did not differ from historical control data $[71,72]$.

\section{Subunit vaccines}

Vacc-4x consists of peptides derived from conserved domains within HIV-1 p24 Gag and induced T-cell responses in $90 \%$ of patients which were associated with reduced viral loads [73]. One and a half years after immunization, Vacc- $4 \mathrm{x}$ responses were unchanged and $62 \%$ were still on ART treatment interruption [74]. Seven years after immunization, $\mathrm{CD}^{+}$and $\mathrm{CD} 8^{+} \mathrm{T}$-cell responses were observed in $95 \%$ and $68 \%$ of subjects, respectively, and $55 \%$ of subjects demonstrated CD107a and IFN- $\gamma \mathrm{CD}^{+} \mathrm{T}$-cell responses. Immunized patients spent a median of 2.2 years free of ART prior to successfully resuming treatment [75]. Subsequent boosting with Vacc-4x 7 years after initial immunization resulted in an increase in $\mathrm{CD} 8^{+} \mathrm{T}$-cell proliferation in $80 \%$ of subjects. Responders demonstrated increased
CD8 ${ }^{+}$T-cell degranulation and $\mathrm{CD} 4^{+} \mathrm{T}$-cell IFN- $\gamma$ expression. Increases in tumor necrosis factor-alpha (TNF- $\alpha$ ) and IL- $1 \alpha$, IL-1 $\beta$, and IL-10 were associated with nonresponders, whereas IL-10- and TGF- $\beta$-mediated downregulation of Vacc-4x-specific $\mathrm{CD} 8^{+} \mathrm{T}$-cell proliferation increased only in non-responders, indicating that boosting with Vacc-4x peptides can enhance T-cell responses but is also capable of promoting regulatory immune responses, highlighting the need to address immune regulation in therapeutic vaccination [76]. Taken together, these studies provided evidence of long-lasting T-cell memory responses to a peptide-based immunotherapeutic candidate for HIV-infected patients [77]. Further studies of Vacc- $4 \mathrm{x}$ include vaccination with the iMiD Revlimid and with an additional vaccine aimed at inducing the production of antibodies to the C5 region of gp120. The $\mathrm{C} 5$ region is thought to influence immune activation, and anti-C5 antibodies are correlated with long-term non-progressor status and HIV-1-specific T-cell responses (unpublished data).

Subdominant peptide epitopes from HIV-1 restricted to common HLA supertypes were used with the adjuvant CAF01 to vaccinate treatment-naïve HIV-1-infected individuals. All 10 patients induced new CD4 and CD8 T-cell responses specific for one or more vaccine epitopes; however, there were no significant changes in HIV-1 viral load or CD4 T-cell counts [78]. These studies on peptide vaccination highlight the importance of selecting optimal peptide combinations for vaccination.

A phase II clinical trial of virologically suppressed ART-treated HIV-1-infected individuals receiving therapeutic immunization with Tat was conducted. Immunization with TAT was safe and induced immune responses, including modifying the pattern of $\mathrm{CD}_{4}^{+}$ and $\mathrm{CD} 8^{+} \mathrm{T}$-cell activation, a reduction in markers of immune activation, and increases in regulatory $\mathrm{T}$ cells (Tregs). Increases in central and effector memory and reduction in terminally differentiated $\mathrm{CD}^{+}$and $\mathrm{CD}^{+} \mathrm{T}$ cells were accompanied by increased responses against Env and recall antigens. Of note, more immune-compromised individuals experienced greater therapeutic effects [79].

Protein and peptide vaccines are among the safest, cheapest, and most stable. They benefit from a relatively simple design allowing for thorough characterization of induced immune responses and avoidance of complications that have been associated with complex vaccine preparations. Peptide vaccines show promise as an immunotherapeutic vaccine strategy alongside restorative immunotherapy. 


\section{Latently infected cells and histone deacetylase inhibitors}

The ability of vaccination or ART treatment to cure HIV-1 infection is limited by the phenomenon of HIV-1 latency. Latency is established, particularly in $\mathrm{CD} 4^{+} \mathrm{T}$ cells, early in infection by unknown mechanisms and is thought to be responsible for viral rebound after ART cessation. Recently, drugs capable of activating HIV-1 replication have been studied with the aim of removing latent viral reservoirs with ART or vaccination [80]. Among these, histone deacetylase (HDAC) inhibitors show promise in reactivating HIV-1 reservoirs and are currently in phase I and II clinical trials. Acetylation of lysine residues found on histone molecules is associated with gene transcription by increasing the accessibility of transcription factors. HDACs deacetylate lysine residues in histone molecules and in so doing prevent transcription. Valproic acid inhibits class I and II HDACs and, in a clinical study of four patients undergoing intensified ART, significantly reduced latent infection in three patients [81].

Vorinostat is a Food and Drug Administration-approved HDAC inhibitor that suppresses HDACs capable of binding to the HIV-1 promoter. In a trial of 11 ARTtreated patients who had no measurable viral plasma RNA but who demonstrated increased ex vivo HIV-1 RNA production in response to Vorinostat, subsequent treatment of these patients resulted in an increase in HIV RNA expression in resting $\mathrm{CD} 4^{+} \mathrm{T}$ cells [82].

Other HDAC inhibitors, targeting different HDACs and first developed as anti-cancer chemotherapy, are being tested for putative in vitro effects on HIV-1 latency [83-85]. Inhibitors targeting class I HDACs are particularly promising since these HDACs are linked to HIV-1 latency [86].

The promising early data using HDAC require further study to determine to what extent they reduce the HIV-1 reservoir and what proportion of latently infected cells are susceptible. A recent study indicated that $\mathrm{T}$ cells with reactivated HIV-1 survive and that antigen-specific cytotoxic immune responses are required to kill these infected cells. This indicates that combinations of HDAC inhibitors with immunotherapeutic vaccination may be required to successfully clear latent viral reservoirs [87].

\section{Conclusions}

The limitations of ART and poor efficacy demonstrated by prophylatic vaccine candidates are well documented. This creates an urgent need for additional therapies, and numerous immunotherapeutic approaches are being investigated, some with encouraging results. The study of therapeutic vaccine formulations capable of activating effective and sustained anti-HIV-1 immune responses warrants continued emphasis. Although non-antigenspecific immunotherapy may prove insufficient to replace ART or allow structured treatment interruptions, it will likely be a necessary prerequisite for effective antiHIV-1 therapeutic vaccination (Figure 1). Studies involving combinations of immunotherapy and therapeutic vaccination are currently lacking but have the potential to correct immune dysfunction and enhance the capacity of the immune system to respond to therapeutic vaccination. The ability to combine immunotherapy, vaccination, and agents capable of reactivating latent viral reservoirs, such as HDAC inhibitors, represents an exciting strategy to develop a functional cure of HIV-1 infection. Many of these approaches are in early clinical development, and the results from current and future trials will provide insight regarding which approaches might best combine to control infection.

At present, both immunotherapy and therapeutic vaccination suffer from a lack of knowledge regarding which immune activation markers represent causative rather than just associated agents of HIV-1 disease progression. The presence of immune activation predicts disease progression independently of viral load and $\mathrm{CD} 4^{+} \mathrm{T}$-cell number, and this creates a difficulty in interpreting the significance of clinical trial data. Many trials do not detail vaccine-specific immune responses and measures of viral

Figure I. Immunotherapy and therapeutic vaccination for HIV-I

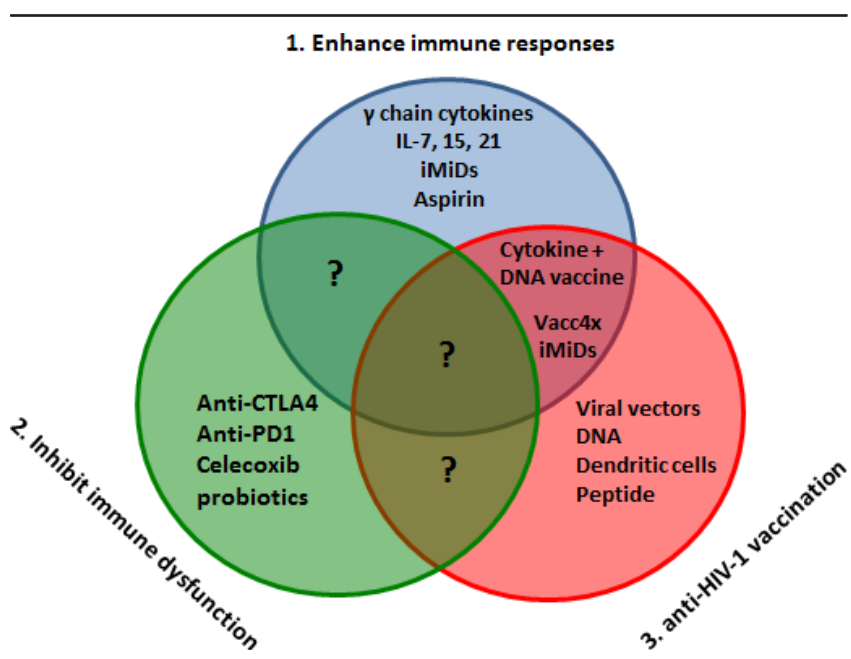

Immunotherapy to enhance immune responses (I) or inhibit immune dysfunction (2) should be studied alongside therapeutic vaccination (3) in order to develop a functional cure consisting of controlled immune responses and repressed viral replication. Abbreviations: CTLA-4, cytotoxic T-lymphocyte antigen 4; IL, interleukin; iMiD, immunomodulatory drug; PD-I, programmed cell death-I. 
replication alongside markers of immune activation. It may be necessary to observe how all three of these correlate change over time during structured treatment interruptions in order to assess the effectiveness of novel therapy. The success of immunotherapy and therapeutic vaccination will depend upon a greater understanding of the causative factors responsible for immune activation and of the immune responses that provide protection in elite controller patients.

\section{Abbreviations}

Ad35, adenovirus serotype 35; ALVAC, recombinant canarypoxvirus; ART, antiretroviral therapy; CCR5, chemokine receptor 5; COX-2, cycloox-ygenase type 2; CTLA4, Cytotoxic T-lymphocyte antigen 4; DC, dendritic cell; HAND, HIV-1-associated neurode-generative disorder; HDAC, histone deacetylase; HIV-1, human immunodeficiency virus-1; HLA, human leukocyte antigen; IFN- $\gamma$, interferon-gamma; IL, interleukin; iMiD, immunomodulatory drug; MDDC, monocytederived dendritic cell; MVA, Modified vaccinia virus Ankara; NYVAC, New York Vaccinia virus; PD-1, programmed cell death-1; rhIL-7, recombinant human IL-7; SIV, simian immunodeficiency virus; TCR, T-cell receptor; TGF- $\beta$, transforming growth factor-beta; Th17, T helper 17.

\section{Disclosures}

The authors declare that they have no disclosures.

\section{References}

I. O'Connell RJ, Kim JH, Corey L, Michael NL: Human Immunodeficiency Virus Vaccine Trials. Cold Spring Harb Perspect Med 2012, 2:a00735I.

2. Rerks-Ngarm S, Pitisuttithum P, Nitayaphan S, Kaewkungwal J, Chiu J, Paris R, Premsri N, Namwat C, de Souza M, Adams E, Benenson M, Gurunathan S, Tartaglia J, McNeil JG, Francis DP, Stablein D, Birx DL, Chunsuttiwat S, Khamboonruang C, Thongcharoen P, Robb ML, Michael NL, Kunasol P, Kim JH; MOPH-TAVEG Investigators: Vaccination with ALVAC and AIDSVAX to prevent HIV-I infection in Thailand. N Engl J Med 2009, 36 I:2209-20.

\section{FlOOOPrime}

3. Hutter G, Nowak D, Mossner M, Ganepola S, Mussig A, Allers K, Schneider T, Hofmann J, Kucherer C, Blau O, Blau IW, Hofmann WK, Thiel E: Long term-control of HIV by CCR5 Delta32/Delta32 stem-cell transplantation. N Eng J Med 2009, 360:692-8.

\section{FlOOOPrime} RECOMMENDED

4. Cohen MS, Smith MK, Muessig KE, Hallett TB, Powers KA, Kashuba AD: Antiretroviral treatment of HIV-I prevents transmission of HIV-I: where do we go from here? Lancet 2013, 382:1515-24

5. Persaud D, Gay H, Ziemniak C, Chen YH, Piatak M Jr, Chun TW, Strain M, Richman D, Luzuriaga K: Absence of detectable HIV-I viremia after treatment cessation in an infant. $N$ Engl J Med 2013, 369:1828-35.

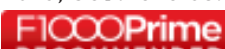
RECOMMENDED
6. Hendrix CW: Exploring concentration response in HIV preexposure prophylaxis to optimize clinical care and trial design. Cell 2013, 155:5।5-8.

7. Barton KM, Burch BD, Soriano-Sarabia N, Margolis DM: Prospects for treatment of latent HIV. Clin Pharmacol Ther 20I3, 93:46-56.

8. Beyrer C, Abdool Karim Q: The changing epidemiology of HIV in 2013. Curr Opin HIV AIDS 2013, 8:306-10.

9. Paula AA, Falcão MC, Pacheco AG: Metabolic syndrome in HIVinfected individuals: underlying mechanisms and epidemiological aspects. AIDS Res Ther 2013, 10:32.

10. Bavinger C, Bendavid E, Niehaus K, Olshen RA, Olkin I, Sundaram V, Wein N, Holodniy M, Hou N, Owens DK, Desai M: Risk of cardiovascular disease from antiretroviral therapy for HIV: a systematic review. PLoS One 2013, 8:e5955I.

II. Gakhar H, Kamali A, Holodniy M: Health-related quality of life assessment after antiretroviral therapy: a review of the literature. Drugs 2013, 73:65I-72.

12. Shubber Z, Calmy A, Andrieux-Meyer I, Vitoria M, Renaud-Théry F, Shaffer N, Hargreaves S, Mills EJ, Ford N: Adverse events associated with nevirapine and efavirenz-based first-line antiretroviral therapy: a systematic review and metaanalysis. AIDS 20I3, 27:1403-12.

13. Ammassari A, Murri R, Pezzotti P, Trotta MP, Ravasio L, De Longis P, Lo Caputo S, Narciso P, Pauluzzi S, Carosi G, Nappa S, Piano P, Izzo CM, Lichtner M, Rezza G, Monforte A, Ippolito G, d'Arminio Moroni M, Wu AW, Antinori A; AdICONA Study Group: Selfreported symptoms and medication side effects influence adherence to highly active antiretroviral therapy in persons with HIV infection. J Acquir Immune Defic Syndr 200I, 28:445-9.

14. Eisfeld C, Reichelt D, Evers S, Husstedt I: CSF penetration by antiretroviral drugs. CNS Drugs 20I3, 27:3I-55.

15. Manji H, Jäger HR, Winston A: HIV: dementia and antiretroviral drugs: 30 years of an epidemic. J Neurol Neurosurg Psychiatry 2013, 84:।126-37.

16. Kranick SM, Nath A: Neurologic complications of HIV-I infection and its treatment in the era of antiretroviral therapy. Continuum (Minneap Minn) 2012, I8:1319-37.

17. Lai RP, Nakiwala JK, Meintjes G, Wilkinson RJ: The immunopathogenesis of the HIV tuberculosis immune reconstitution inflammatory syndrome. Eur J Immunol 2013, 43:1995-2002.

18. Luetkemeyer AF, Kendall MA, Nyirenda M, Wu X, Ive P, Benson CA, Andersen JW, Swindells S, Sanne IM, Havlir DV, Kumwenda J: Tuberculosis Immune Reconstitution Inflammatory Syndrome in A522 I STRIDE: Timing, Severity and Implications for HIV-TB programs. J Acquir Immune Defic Syndr 2013, 65:423-8.

19. Deeks SG, Lewin SR, Havlir DV: The end of AIDS: HIV infection as a chronic disease. Lancet 2013, 382:1525-33. FlOOOPrime

20. Reekie J, Kowalska JD, Karpov I, Rockstroh J, Karlsson A, Rakhmanova A, Horban A, Kirk O, Lundgren JD, Mocroft A; EuroSIDA in EuroCoord: Regional differences in AIDS and non-AIDS related mortality in HIV-positive individuals across Europe and Argentina: the EuroSIDA study. PLoS One 20I2, 7:e41673.

21. Corbeau P, Reynes J: Immune reconstitution under antiretroviral therapy: the new challenge in HIV-I infection. Blood 20II, I I 7:5582-90.

22. Brenchley JM, Price DA, Schacker TW, Asher TE, Silvestri G, Rao S, Kazzaz Z, Bornstein E, Lambotte O, Altmann D, Blazar BR, Rodriguez B, Teixeira-Johnson L, Landay A, Martin JN, Hecht FM, Picker LJ, Lederman MM, Deeks SG, Douek DC: Microbial translocation is a cause of systemic immune activation in chronic HIV infection. Nat Med 2006, I 2: |365-7|.

FlOOOPrime RECOMMENDED

23. Brenchley JM, Schacker TW, Ruff LE, Price DA, Taylor JH, Beilman G], Nguyen PL, Khoruts A, Larson M, Haase AT, Douek DC: CD4+ T cell 
depletion during all stages of HIV disease occurs predominantly in the gastrointestinal tract. J Exp Med 2004, 200:749-59.

\section{FlOOOPrime}

24. Mehandru S, Poles MA, Tenner-Racz K, Horowitz A, Hurley A, Hogan C, Boden D, Racz P, Markowitz M: Primary HIV-I infection is associated with preferential depletion of CD4+ T lymphocytes from effector sites in the gastrointestinal tract. $J$ Exp Med I2004, 200:76I-70.

25. Brenchley JM, Paiardini M, Knox KS, Asher Al, Cervasi B, Asher TE, Scheinberg P, Price DA, Hage CA, Kholi LM, Khoruts A, Frank I, Else J, Schacker T, Silvestri G, Douek DC: Differential ThI7 CD4 T-cell depletion in pathogenic and nonpathogenic lentiviral infections. Blood 2008, I I 2:2826-35.

26. Porichis F, Kaufmann DE: Role of PD-I in HIV pathogenesis and as a target for Therapy. Curr HIVIAIDS Rep 20II, 24:8I-90.

27. Porichis F, Hart MG, Zupkosky J, Barblu L, Kwon DS, McMullen A, Brennan T, Ahmed R, Freeman G], Kavanagh DG, Kaufmann DE: Differential impact of PD-I and/or IL-IO blockade on HIV-Ispecific CD4 $\mathrm{T}$ cell and antigen-presenting cell functions. J Virol 2013, 88:2508-18.

28. Ramsay AG: Immune checkpoint blockade immunotherapy to activate anti-tumour T-cell immunity. $\mathrm{Br} J$ Haematol 2013, 162:313-25.

29. Hryniewicz A, Boasso A, Edghill-Smith $Y$, Vaccari M, Fuchs D, Venzon D, Nacsa J, Betts MR, Tsai WP, Heraud JM, Beer B, Blanset D, Chougnet C, Lowy I, Shearer GM, Franchini G: CTLA-4 blockade decreases TGF-beta, IDO, and viral RNA expression in tissues of SIVmac25I-infected macaques. Blood 2006, I08: 3834-42.

\section{FlOOOPrime}

30. Leng Q, Bentwich Z, Magen E, Kalinkovich A, Borkow G: CTLA-4 upregulation during HIV infection: association with anergy and possible target for therapeutic intervention. AIDS 2002, 16:519-29.

\section{FlOOOPrime}

\section{RECOMMENDED}

31. van Lelyveld SF, Wensing AM, Hoepelman Al: The MOTIVATE trials: maraviroc therapy in antiretroviral treatmentexperienced HIV-I-infected patients. Expert Rev Anti Infect Ther 2012, I0: |24|-7.

32. Westrop SJ, Moyle G, Jackson A, Nelson M, Mandalia S, Imami N: CCR5 antagonism impacts vaccination response and immune profile in HIV-I infection. Mol Med 20I2, 18:1240-8.

\section{FlOOOPrime}

\section{RECOMMENDED}

33. Emery S, Capra WB, Cooper DA, Mitsuyasu RT, Kovacs JA, Vig P, Smolskis M, Saravolatz LD, Lane HC, Fyfe GA, Curtin PT: Pooled analysis of 3 randomized, controlled trials of interleukin-2 therapy in adult human immunodeficiency virus type I disease. J Infect Dis 2000, 182:428-34.

34. Molina JM, Levy Y, Fournier I, Hamonic S, Bentata M, Beck-Wirth G, Gougeon ML, Venet A, Madelaine I, Sereni D, Jeanblanc F, Boulet T, Simon F, Aboulker JP: Interleukin-2 before antiretroviral therapy in patients with HIV infection: a randomized trial (ANRS I I 9). J Infect Dis 2009, 200:206-15.

35. INSIGHT-ESPRIT Study Group; SILCAAT Scientific Committee. Abrams D, Lévy Y, Losso MH, Babiker A, Collins G, Cooper DA, Darbyshire J, Emery S, Fox L, Gordin F, Lane HC, Lundgren JD, Mitsuyasu R, Neaton JD, Phillips A, Routy JP, Tambussi G, Wentworth D: Interleukin-2 therapy in patients with HIV infection. N Engl J Med 2009, 36 I:1548-59.

\section{FlOOOPrime}

RECOMMENDED

36. Bosch RJ, Pollard RB, Landay A, Aga E, Fox L, Mitsuyasu R: AIDS Clinical Trials Group A5I32 Team. A randomized trial of interleukin-2 during withdrawal of antiretroviral treatment. J Interferon Cytokine Res 20I I, 3 I:48I-3.
37. Pallikkuth S, Rogers K, Villinger F, Dosterii M, Vaccari M, Franchini G, Pahwa R, Pahwa S: Interleukin-2I administration to rhesus macaques chronically infected with simian immunodeficiency virus increases cytotoxic effector molecules in T cells and NK cells and enhances B cell function without increasing immune activation or viral replication. Vaccine 2011 , 29:9229-38.

\section{FlOOOPrime
RECOMMENDED}

38. Pallikkuth S, Micci L, Ende ZS, Iriele RI, Cervasi B, Lawson B, McGary CS, Rogers KA, Else JG, Silvestri G, Easley K, Estes JD, Villinger F, Pahwa S, Paiardini M: Maintenance of intestinal ThI7 cells and reduced microbial translocation in SIV-infected rhesus macaques treated with interleukin (IL)-2I. PLoS Pathog 20I3, 9:el00347I.

\section{FIOOOPrime
RECOMMENDED}

39. Lévy Y, Sereti I, Tambussi G, Routy JP, Lelièvre JD, Delfraissy JF, Molina JM, Fischl M, Goujard C, Rodriguez B, Rouzioux C, AvettandFenoël V, Croughs T, Beq S, Morre M, Poulin JF, Sekaly RP, Thiebaut R, Lederman MM: Effects of recombinant human interleukin 7 on T-cell recovery and thymic output in HIVinfected patients receiving antiretroviral therapy: results of a phase I/Ila randomized, placebo-controlled, multicenter study. Clin Infect Dis 2012, 55:291-300.

\section{FlOOOPrime
RECOMMENDED}

40. O’Brien M, Montenont E, Hu L, Nardi MA, Valdes V, Merolla M, Gettenberg G, Cavanagh K, Aberg JA, Bhardwaj N, Berger JS: Aspirin attenuates platelet activation and immune activation in HIV-I-infected subjects on antiretroviral therapy: a pilot study. J Acquir Immune Defic Syndr 2013, 63:280-8.

\section{FlOOOPRime
RECOMMENDED}

4I. Pettersen FO, Torheim EA, Dahm AE, Aaberge IS, Lind A, Holm M, Aandahl EM, Sandset PM, Taskén K, Kvale D: An exploratory trial of cyclooxygenase type 2 inhibitor in HIV-I infection: downregulated immune activation and improved $\mathrm{T}$ cell-dependent vaccine responses. J Virol 2011, 85:6557-66.

\section{FlOOOPrime}

RECOMMENDED

42. Galustian C, Meyer B, Labarthe MC, Dredge K, Klaschka D, Henry J, Todryk S, Chen R, Muller G, Stirling D, Schafer P, Bartlett JB, Dalgleish AG: The anti-cancer agents lenalidomide and pomalidomide inhibit the proliferation and function of T regulatory cells. Cancer Immunol Immunother 2009, 58: 1033-45.

43. Bodera P, Stankiewicz W: Immunomodulatory properties of thalidomide analogs: pomalidomide and lenalidomide, experimental and therapeutic applications. Recent Pat Endocr Metab Immune Drug Discov 20I I, 5:192-6.

44. Henry JY, Labarthe MC, Meyer B, Dasgupta P, Dalgleish AG, Galustian $C$ : Enhanced cross-priming of naive CD8+ $T$ cells by dendritic cells treated by the IMiDs $®$ immunomodulatory compounds lenalidomide and pomalidomide. Immunology 2013, 139:377-85.

45. Sakamaki I, Kwak LW, Cha SC, Yi Q, Lerman B, Chen J, Surapaneni S, Bateman S, Qin H: Lenalidomide enhances the protective effect of a therapeutic vaccine and reverses immune suppression in mice bearing established lymphomas. Leukemia 2014, 28:329-37.

46. De Keersmaecker B, Allard SD, Lacor P, Schots R, Thielemans K, Aerts JL: Expansion of polyfunctional HIV-specific T cells upon stimulation with mRNA electroporated dendritic cells in the presence of immunomodulatory drugs. Virol 20I2, 86:935I-60.

\section{FIOOOPrime}

47. Rueda CM, Velilla PA, Chougnet CA, Montoya CJ, Rugeles MT: HIVinduced $\mathrm{T}$-cell activation/exhaustion in rectal mucosa is 
controlled only partially by antiretroviral treatment. PLoS One 2012, 7:e30307.

48. Schunter M, Chu H, Hayes TL, McConnell D, Crawford SS, Luciw PA, Bengmark S, Asmuth DM, Brown J, Bevins CL, Shacklett BL, Critchfield JW: Randomized pilot trial of a synbiotic dietary supplement in chronic HIV-I infection. BMC Complement Altern Med 2012, I 2:84

\section{FlOOOPrime}

\section{RECOMMENDED}

49. González-Hernández LA, Jave-Suarez LF, Fafutis-Morris M, MontesSalcedo KE, Valle-Gutierrez LG, Campos-Loza AE, Enciso-Gómez LF, Andrade-Villanueva JF: Synbiotic therapy decreases microbial translocation and inflammation and improves immunological status in HIV-infected patients: a double-blind randomized controlled pilot trial. Nutr J 2012, I I:90.

50. Walker B, McMichael A: The T-cell Response to HIV. Cold Spring Harb perspect Med 2012, 2:a007054

5I. Pereyra F, Addo MM, Kaufmann DE, Liu Y, Miura T, Rathod A, Baker B, Trocha A, Rosenberg R, Mackey E, Ueda P, Lu Z, Cohen D, Wrin T, Petropoulos C], Rosenberg ES, Walker BD: Genetic and immunologic heterogeneity among persons who control HIV infection in the absence of therapy. J Infect Dis 2008, 197:563-7I.

\section{FIOOOPrime
RECOMMENDED}

52. Poropatich K, Sullivan DJ Jr: Human immunodeficiency virus type I long-term non-progressors: the viral, genetic and immunological basis for disease non-progression. J Gen Virol 2011, 92:247-68.

\section{FlOOOPrime} RECOMMENDED

53. Blankson JN: Effector mechanisms in HIV-I infected elite controllers: highly active immune responses? Antiviral Res 2010 , 85:295-302.

54. Gomez CE, Perdiguero B, Garcia-Arriaza J, Esteban M: Poxvirus vectors as HIVIAIDS vaccines in hiumans. Hum Vaccin Immunother 2012, 8: $1192-207$.

55. Rerks-Ngarm S, Paris RM, Chunsutthiwat S, Premsri N, Namwat C, Bowonwatanuwong C, Li SS, Kaewkungkal J, Trichavaroj R, Churikanont N, de Souza MS, Andrews C, Francis D, Adams E, Flores J, Gurunathan S, Tartaglia J, O'Connell RJ, Eamsila C, Nitayaphan S, Ngauy V, Thongcharoen P, Kunasol P, Michael NL, Robb ML, Gilbert PB, Kim JH: Extended evaluation of the virologic, immunologic, and clinical course of volunteers who acquired HIV-I infection in a phase III vaccine trial of ALVAC-HIV and AIDSVAX B/E. I Infect Dis 2013, 207: | 195-205.

\section{FlOOOPrime}

56. García F, Bernaldo de Quirós JC, Gómez CE, Perdiguero B, Nájera JL, liménez V, García-Arriaza J, Guardo AC, Pérez I, Díaz-Brito V Conde MS, González N, Alvarez A, Alcamí J, Jiménez JL, Pich J, Arnaiz JA, Maleno MJ, León A, Muñoz-Fernández MA, Liljeström P, Weber J, Pantaleo G, Gatell JM, Plana M, Esteban M: Safety and immunogenicity of a modified pox vector-based HIVIAIDS vaccine candidate expressing Env, Gag, Pol and Nef proteins of HIV-I subtype B (MVA-B) in healthy HIV-I-uninfected volunteers: A phase I clinical trial (RISVAC02). Vaccine $201 \mathrm{I}$, 29:8309-16.

57. Gómez CE, Nájera JL, Perdiguero B, García-Arriaza J, Sorzano CO, Jiménez V, González-Sanz R, Jiménez JL, Muñoz-Fernández MA, López Bernaldo de Quirós JC, Guardo AC, García F, Gatell JM, Plana M, Esteban M: The HIVIAIDS vaccine candidate MVA-B administered as a single immunogen in humans triggers robust, polyfunctional, and selective effector memory $T$ cell responses to HIV-I antigens. J Virol 20I I, 85: I |468-78.

\section{FlOOOPrime \\ RECOMMENDED}

58. Harari A, Bart PA, Stöhr W, Tapia G, Garcia M, Medjitna-Rais E, Burnet S, Cellerai C, Erlwein O, Barber T, Moog C, Liljestrom P, Wagner R, Wolf $\mathrm{H}$, Kraehenbuhl JP, Esteban M, Heeney J,
Frachette MJ, Tartaglia J, McCormack S, Babiker A, Weber J, Pantaleo G: An HIV-I clade C DNA prime, NYVAC boost vaccine regimen induces reliable, polyfunctional, and longlasting $\mathbf{T}$ cell responses. J Exp Med 2008, 205:63-77.

\section{FlOOOPrime
RECOMMENDED}

59. McCormack S, Stöhr W, Barber T, Bart PA, Harari A, Moog C, Ciuffreda D, Cellerai C, Cowen M, Gamboni R, Burnet S, Legg K, Brodnicki E, Wolf H, Wagner R, Heeney J, Frachette MJ, Tartaglia J, Babiker A, Pantaleo G, Weber J: EV02: a Phase I trial to compare the safety and immunogenicity of HIV DNA-C prime-NYVAC-C boost to NYVAC-C alone. Vaccine 2008, 26:3 162-74.

60. Keefer MC, Gilmour J, Hayes P, Gill D, Kopycinski J, Cheeseman H, Cashin-Cox M, Naarding M, Clark L, Fernandez N, Bunce CA, Hay CM, Welsh S, Komaroff W, Hachaambwa L, Tarragona-Fiol T, Sayeed E, Zachariah D, Ackland J, Loughran K, Barin B, Cormier E, Cox JH, Fast P, Excler JL: A phase I double blind, placebocontrolled, randomized study of a multigenic HIV-I adenovirus subtype 35 vector vaccine in healthy uninfected adults. PLoS One 7:e41936.

\section{FlOOOPrime
RECOMMENDED}

6I. Wecker M, Gilbert P, Russell N, Hural J, Allen M, Pensiero M, Chulay J, Chiu YL, Abdool Karim SS, Burke DS; HVTN 040/059 Protocol Team; NIAID HIV Vaccine Trials Network: Phase I safety and immunogenicity evaluations of an alphavirus replicon HIV-I subtype C gag vaccine in healthy HIV-I-uninfected adults. Clin Vaccine Immunol 2012, 19:1651-60.

62. Kalams SA, Parker SD, Elizaga M, Metch B, Edupuganti S, Hural J, De Rosa S, Carter DK, Rybczyk K, Frank I, Fuchs J, Koblin B, Kim DH, Joseph P, Keefer MC, Baden LR, Eldridge J, Boyer J, Sherwat A, Cardinali M, Allen M, Pensiero M, Butler C, Khan AS, Yan J, Sardesai NY, Kublin JG, Weiner DB; NIAID: HIV Vaccine Trials Network. Safety and comparative immunogenicity of an HIV-I DNA vaccine in combination with plasmid interleukin 12 and impact of intramuscular electroporation for delivery. J Infect Dis 2013, 208:818-29.

63. Somogyi E, Xu J, Gudics A, Tóth J, Kovács AL, Lori F, Lisziewicz J: A plasmid DNA immunogen expressing fifteen protein antigens and complex virus-like particles (VLP+) mimicking naturally occurring HIV. Vaccine 20I I, 29:744-53.

64. Lori F, Trocio J, Bakare N, Kelly LM, Lisziewicz J: DermaVir, a novel HIV immunisation technology. Vaccine 2005, 23:2030-4.

65. Rodriguez B, Asmuth DM, Matining RM, Spritzler J, Jacobson JM, Mailliard RB, Li XD, Martinez Al, Tenorio AR, Lori F, Lisziewicz J, Yesmin S, Rinaldo CR, Pollard RB: Safety, tolerability, and immunogenicity of repeated doses of dermavir, a candidate therapeutic HIV vaccine, in HIV-infected patients receiving combination antiretroviral therapy. J Acquir Immune Defic Syndr 2013, 64:351-9.

66. Calarota SA, Dai A, Trocio JN, Weiner DB, Lori F, Lisziewicz J: IL-I5 as memory T-cell adjuvant for topical HIV-I DermaVir vaccine. Vaccine 2008, 26:5188-95.

67. Blazevic $V$, Männik $A$, Malm $M$, Sikut $R$, Valtavaara $M$, Toots $U$, Ustav M, Krohn K: Induction of human immunodeficiency virus type-I-specific immunity with a novel gene transport unit (GTU)-MultiHIV DNA vaccine. AIDS Res Hum Retroviruses 2006, 22:667-77.

68. Vardas E, Stanescu I, Leinonen M, Ellefsen K, Pantaleo G, Valtavaara M, Ustav M, Reijonen K: Indicators of therapeutic effect in FIT-06, a Phase II trial of a DNA vaccine, GTU (®)-Multi-HIVB, in untreated HIV-I infected subjects. Vaccine 2012, 30:4046-54.

69. Hutnick NA, Myles DJ, Bian CB, Muthumani K, Weiner DB: Selected approaches for increasing HIV DNA vaccine immunogenicity in vivo. Curr Opin Virol 2011, I:233-40.

70. García F, Climent N, Guardo AC, Gil C, León A, Autran B, Lifson JD, Martínez-Picado J, Dalmau J, Clotet B, Gatell JM, Plana M, Gallart T; DCV2/MANON07-ORVACS Study Group: A dendritic cell-based 
vaccine elicits $T$ cell responses associated with control of HIV-I replication. Sci Transl Med 2013, 5:I66ra2.

\section{FlOOOPrime RECOMMENDED}

7I. Allard SD, Pletinckx K, Breckpot K, Heirman C, Bonehill A, Michiels A, van Baalen CA, Gruters RA, Osterhaus AD, Lacor P, Thielemans K, Aerts JL: Functional T-cell responses generated by dendritic cells expressing the early HIV-I proteins Tat, Rev and Nef. Vaccine 2008, 26:3735-4I.

72. Allard SD, De Keersmaecker B, de Goede AL, Verschuren EJ, Koetsveld J, Reedijk ML, Wylock C, De Bel AV, Vandeloo J, Pistoor F, Heirman C, Beyer WE, Eilers PH, Corthals J, Padmos I, Thielemans K, Osterhaus AD, Lacor P, van der Ende ME, Aerts JL, van Baalen CA, Gruters RA: A phase I/Ila immunotherapy trial of HIV-Iinfected patients with Tat, Rev and Nef expressing dendritic cells followed by treatment interruption. Clin Immunol 2012, | 42:252-68

\section{FlOOOPrime}

\section{RECOMMENDED}

73. Kran AM, Sørensen B, Nyhus J, Sommerfelt MA, Baksaas I, Bruun JN, Kvale D: HLA- and dose-dependent immunogenicity of a peptide-based HIV-I immunotherapy candidate (Vacc-4x). AIDS 2004, 18:1875-83

74. Kran AM, Sørensen B, Sommerfelt MA, Nyhus J, Baksaas I, Kvale D: Long-term HIV-specific responses and delayed resumption of antiretroviral therapy after peptide immunization targeting dendritic cells. AIDS 2006, 20:627-30.

75. Lind A, Sommerfelt M, Holmberg JO, Baksaas I, Sørensen B, Kvale D: Intradermal vaccination of HIV-infected patients with short HIV Gag p24-like peptides induces CD4 + and CD8 + T cell responses lasting more than seven years. Scand J Infect Dis 2012, 44:566-72.

FlOOOPrime
RECOMMENDED

76. Lind A, Brekke K, Sommerfelt M, Holmberg JO, Aass HC, Baksaas I, Sørensen B, Dyrhol-Riise AM, Kvale D: Boosters of a therapeutic $H I V-I$ vaccine induce divergent $T$ cell responses related to regulatory mechanisms. Vaccine 2013, 3 I:46I I-8.

77. Kran AM, Sommerfelt MA, Baksaas I, Sørensen B, Kvale D: Delayedtype hypersensitivity responses to HIV Gag p24 relate to clinical outcome after peptide-based therapeutic immunization for chronic HIV infection. APMIS 20I2, 1 20:204-9.

78. Karlsson I, Brandt L, Vinner L, Kromann I, Andreasen LV, Andersen P, Gerstoft ], Kronborg G, Fomsgaard A: Adjuvanted HLA-supertype restricted subdominant peptides induce new T-cell immunity during untreated HIV-I-infection. Clin Immunol 20I3, I46:I20-30.

79. Ensoli B, Bellino S, Tripiciano A, Longo O, Francavilla V, Marcotullio S, Cafaro A, Picconi O, Paniccia G, Scoglio A, Arancio A, Ariola C, Ruiz Alvarez MJ, Campagna M, Scaramuzzi D, lori C, Esposito R, Mussini C,
Ghinelli F, Sighinolfi L, Palamara G, Latini A, Angarano G, Ladisa N, Soscia F, Mercurio VS, Lazzarin A, Tambussi G, Visintini R, Mazzotta F, Di Pietro M, Galli M, Rusconi S, Carosi G, Torti C, Di Perri G, Bonora S, Ensoli F, Garaci E: Therapeutic immunization with HIV-I Tat reduces immune activation and loss of regulatory $T$-cells and improves immune function in subjects on HAART. PLoS One 2010, 5:el3540.

80. Shirakawa K, Chavez L, Hakre S, Calvanese V, Verdin E: Reactivation of latent HIV by histone deacetylase inhibitors. Trends Microbiol 2013, 6:277-85.

8I. Lehrman G, Hogue IB, Palmer S, Jennings C, Spina CA, Wiegand A, Landay AL, Coombs RW, Richman DD, Mellors JW, Coffin JM, Bosch RJ, Margolis DM: Depletion of latent HIV-I infection in vivo: a proof-of-concept study. Lancet 2005, 366:549-55.

\section{FIOOOPrime}

82. Archin NM, Liberty AL, Kashuba AD, Choudhary SK, Kuruc JD, Crooks AM, Parker DC, Anderson EM, Kearney MF, Strain MC, Richman DD, Hudgens MG, Bosch RJ, Coffin JM, Eron J], Hazuda DJ, Margolis DM: Administration of vorinostat disrupts HIV-I latency in patients on antiretroviral therapy. Nature 487:482-5.

\section{FlOOOPrime}

\section{RECOMMENDED}

83. Matalon S, Palmer BE, Nold MF, Furlan A, Kassu A, Fossati G, Mascagni $P$, Dinarello $C A$ : The histone deacetylase inhibitor ITF2357 decreases surface CXCR4 and CCR5 expression on CD4(+) T-cells and monocytes and is superior to valproic acid for latent HIV-I expression in vitro. J Acquir Immune Defic Syndr 2010, 54:1-9.

84. Atadja P: Development of the pan-DAC inhibitor panobinostat (LBH589): successes and challenges. Cancer Lett 2009, 280:233-4I.

85. Archin NM, Keedy KS, Espeseth A, Dang H, Hazuda DJ, Margolis DM: Expression of latent human immunodeficiency type $I$ is induced by novel and selective histone deacetylase inhibitors. AIDS 2009, 23:1799-806.

86. Keedy KS, Archin NM, Gates AT, Espeseth A, Hazuda DJ, Margolis DM: A limited group of class I histone deacetylases acts to repress human immunodeficiency virus type I expression. J Virol 2009, 83:4749-56.

\section{FlOOOPrime
RECOMMENDED}

87. Shan L, Deng K, Shroff NS, Durand CM, Rabi SA, Yang HC, Zhang H, Margolick JB, Blankson JN, Siliciano RF: Stimulation of HIV-I-specific cytolytic $\mathrm{T}$ lymphocytes facilitates elimination of latent viral reservoir after virus reactivation. Immunity 20I2, 36:49I-50I. 